\title{
EFL Learners' Perceptions on Schoology Use in the Reading Class
}

\author{
Ahmad Ridho Rojabi \\ IAIN Jember, Indonesia \\ Correspondence: Ahmad Ridho Rojabi, IAIN Jember, Indonesia. e-mail:ahmadridhorojabi@gmail.com \\ Submitted: March 01, 2021 \\ Revised: March 14, 2021 \\ Accepted: March 28, 2021 \\ DOI: 10.29408/veles.3219.v5i1 \\ URL: http://dx.doi.org/10.29408/veles.3219.v5i1
}

\begin{abstract}
Online learning that is integrated into face-to-face learning called blended learning is believed to be more useful than online learning or face-to-face learning. Schoology is one of the online learning platforms exploited in blended learning that can help teachers to manage classroom information. Schoology allows students and teachers to share information and provides access to content or administrative features of specific courses. This study aims to investigate students' perceptions of blended learning via Schoology in reading class. This is a descriptive study, the participants of this study consisted of 28- second-semester students at the English Language Study Program, Faculty of Tarbiyah, and teacher training IAIN Jember, East Java Indonesia. The Data were collected through questionnaires and interviews. The findings of this study revealed that there were positive perceptions of blended learning via Schoology in the reading comprehension class as well as the positive learners' attitude. Furthermore, the students agreed that Schoology in blended learning in the reading comprehension class is useful, helpful, and effective. Moreover, from the results of the interviews, there were positive aspects of blended learning via Schoology in reading comprehension which gave more benefits to engage and motivate students' learning activities, students' performances, learners' autonomy, as well as students' learning outcomes
\end{abstract}

Keywords: attitude, blended learning, perception, reading comprehension, Schoology

\section{Introduction}

In the digital age when technology is rapidly developing, many people enjoy the various conveniences provided by technology. Communication and interaction have become easier due to the invention of Internet technology and sophisticated communication tools. This has had several impacts on various fields including education. Teaching and learning focus more on learning than on teaching, where the role of the teacher is to be a facilitator, a knowledge navigator, and a student's companion rather than a conveyor of information. The shift in the role of teachers can be reduced by advanced technology, and teachers and education practitioners can increase their role in facilitating learning by utilizing technology (Low, 2017). A variety of aspects of education have been changed by emerging technology such as artificial intelligence 
tools and educational software, along with changing the field for students, restructuring the role of educators, developing improvements in teaching methods, and remodeling classrooms (Bernard, 2017). Thus, it is important for the teachers in designing mobile learning that utilizes mobile devices at a convenient time.

Mobile learning should help teachers as well as learners in optimizing accessibility (Kumar Basak et al., 2018). Mobile learning has attributes that contribute to its term, namely; spontaneous, personal, informal, contextual, portable, ubiquitous, and pervasive (KukulskaHulme, 2009). This implies that these characteristics refer to the concept of the mobile itself so that it can provide a process of learning anytime and anywhere when used in education. Besides, mobile learning has created a flexible learning platform that enables students to interact with online learning platforms, to engage with the learning resources provided on platforms, and to learn anywhere and anytime (Mehdipour \& Zerehkafi, 2013). This means that the fundamental features of mobile learning are mobility, portability, and the convenience of learning anywhere and anytime.

Teaching reading through technology can facilitate student engagement and increase learning motivation (Dreyer \& Nel, 2003). Besides, technology can be a means to practice reading skills based on the interests and needs of each student by meeting various reading goals (Butler-Pascoe \& Wiburg, 2003). Most EFL learning is usually class-based and/or teachercentered rather than concentrating on students and their needs both in and out of the classroom. However, there is already a growing interest in updating theoretical assumptions and new educational methodological approaches that can support effective learning, particularly under circumstances that are collaborative, authentic, and meaningful ( $\mathrm{Hu}, 2010)$. In other words, learning technology or mobile devices can strengthen students' knowledge, experience, and learning opportunities for reading.

However, there are still many problems in EFL classes. Many students do not get enough English learning; they have poor English skills, especially in reading comprehension. Students do not have enough vocabulary, and they do not have a good reading interest and appropriate learning methods. Most students only learn English in the classroom and need more time outside the classroom to study independently. In each class meeting, students only have 100-150 minutes. Therefore, by assigning them more duties, lecturers need to have more time outside the classroom for students to study. So, after class, students are expected to complete their assignments. Besides, according to the researcher's observations, students feel bored in doing conventional tasks because they face long reading texts and difficult vocabularies, especially reading texts from TOEFL and IELTS. Students can read quickly but they are not able to understand the reading text well and are unable to retell the reading content in their own words. Responding to the problems above, blended learning is believed to have a benefit in motivating students in teaching and learning activities of reading.

In higher education, blended learning is seen as effective learning to improve diverse student learning experiences. Blended learning combines and complements face-to-face learning and online learning (Poon, 2013). In blended learning, students are asked to prepare learning 
activities to learn online according to their level of understanding, have in-depth discussions, ask questions, and provide personal feedback (Wanner, T., \& Palmer, 2015). The above approach is expected able to influence students' perceptions of the learning environment, which in turn has an impact on their learning approach and learning outcomes.

Many experts have given their definition of the blended learning concept. The term 'blending' has recently been associated with e-learning so blended learning is a mixture of elearning and traditional teaching methods (Littlejohn \& Pegler, 2007). Blended learning is a "design approach in which face-to-face and online learning are made better with the presence of another and the combination of offline and online learning allows one to complement the other (Garrison \& Vaughan, 2008). In brief, blended learning is defined as a learning approach that combines offline learning methods with online learning methods, and each learning method is complementary to one another for better learning quality.

Schoology is an online learning platform, or also recognized as a Learning Management System (LMS) has been exploited for online learning and blended learning by various institutions in many countries. By utilizing the Schoology web, teachers can motivate students to share ideas and solve problems for the individual benefit of students or the school community (Biswas, 2018). In this case, the teacher can motivate students to discuss in the comments column, and to add, create, and share supporting materials (for example, audio, video, pages, images). However, Schoology's deficiencies include the possibility for students to become distracted, limited accounts that can be accessed at the same time on one computer, and the low moderation of comments and discussions from students. Since Schoology is a closed system, any posts posted on Schoology will not be shared with people outside Schoology, and students find it a bit difficult to build their social media relations because they are mediated by teachers.

Perception is defined as someone's opinion or thoughts about something he has learned either agrees with or disagrees based on his experience, the results of his observations, or based on existing external factors in his personality (Hong et al., n.d.; Susuwele-Banda, 2005). In this study, students gave their thoughts about the online learning environment via Schoology. Students' perceptions related to the benefits, challenges, attitudes, and how the interaction of student-student as well as students-teachers in learning via Schoology.

Attitude is a relatively persistent organization of trust around an object or situation, where someone is likely to respond in a certain way. An attitude that is relatively enduring because someone wants to learn it, or he does not want to learn it. As something is learned, it can be taught. If the student enters the language class with a sufficiently neutral, or positive attitude, it will allow him to have openness and willingness to accept and respond. His attitude about the desire to learn the language will be greatly influenced by its situation. A student who does not like studying or going to school, who does not like meeting his teacher and who does not want to do his homework, quickly generalized his dislike. Hence a good attitude and feel are required to motivate the students in language learning classes (Oroujlou, N., \& Vahedi, 2011).

Non-experimental research with a quantitative and qualitative approach entitled 'Tenth Grade Students' Perception of Developed Online Reading Materials through Schoology" was 
conducted by Christianti. Her research aims to find out students' perceptions rather than giving treatment. Participants were 40 students using a questionnaire and interview method. The result of the research is that online reading material uploaded in Schoology provides benefits and positive attitudes for some students (Christianti, 2020).

Another study with a qualitative approach entitled "Learners' Perception on their Online Reading Comprehension Learning at the English Education Department of the University of Islam Malang" was also carried out by Untari. The participants were 30 second-semester students of the English Education Department Class 2A and 2B with 30 questionnaires of students' perceptions of reading online understanding through the Google form as the instrument. The results of her research revealed that most of the students felt comfortable and enjoyed learning to read online materials on Schoology, they enhanced their vocabularies, and they also focused on evaluation during that semester (Untari et al., 2020).

The previous research above identified the learners' perceptions of online reading materials on Schoology, benefits as well challenges. However, those prior research did not address the learners' engagement in blended learning via Schoology on how the student-student and studentteacher interact with each other. Regarding these considerations, this study aims to capture students' perceptions and attitudes in Schoology-based blended learning as an online learning platform and it is hoped that Schoology provides benefits in engaging and motivating students in reading comprehension activities. By doing so, the learners can enhance their learning outcomes.

\section{Method}

\subsection{Research Design}

This research design is classified as qualitative research. This qualitative research involves collecting and analyzing data to understand the concepts, perceptions, as well attitudes. The purpose of this study was to obtain information about the perceptions and attitudes of EFL students about blended learning via Schoology.

\subsection{Research Participant}

The research participants were recruited purposively which consisted of 28- secondsemester students in the English Study Program, Faculty of Tarbiyah and Teacher Training of IAIN Jember. The students were recruited as they were intended to be able to provide required information dealing with research questions. The Participants were enrolled in the Intensive Reading Course and they met in class once a week. The lecture lasts 100 minutes for 16 meetings. At the start of the semester, the researcher introduced Schoology which is used for all participants. It is used to share information, assignments, materials, or text links. Besides, Schoology is used to discuss their thoughts with colleagues or submit their assignments to lecturers. This means that after reading comprehension in class, students continue to learn to understand and discuss some of the texts uploaded by lecturers/instructors through Schoology. The lecturer shares information related to assignments or discussion topics to Schoology once to three times a week. 


\subsection{Research Instrument}

In this study, there are three research questions. The first question is to identify students' perceptions of Schoology-based blended learning in the Reading class, the second question is to find out students' attitudes about Schoology-based blended learning in the Reading class. While the third question is to find out the benefits as well as challenges of Schoology-based blended learning in the Reading class. To answer the three research questions, researchers used a questionnaire, observation, and interviews as instruments in this study.

The questionnaires were adapted from the theory of blended learning framework about learning effectiveness, learner satisfaction, faculty satisfaction, access, and cost-effectiveness (Moore, 2013). There were 16 researcher-made questionnaires in this study dealing with the above theory, and they were checked by two experts, one expert is from the State Islamic Institute of Jember and another expert is from the University of Jember for relevance and content validity. To strengthen the data, an interview was conducted for follow-up if there were incomplete data on the questionnaire.

\section{Results and Discussion}

\subsection{Results}

Validity and Reliability Test for the Questionnaire

Table 1 . Validity and Reliability Test

\begin{tabular}{llllllll}
\hline $\begin{array}{l}\text { Item } \\
\text { s }\end{array}$ & r-observation & sig & $\begin{array}{l}\text { r-critical } \\
\text { value }\end{array}$ & Conclusion & $\begin{array}{l}\text { Cronbach's } \\
\text { Alpha }\end{array}$ & $\begin{array}{l}\text { Critical } \\
\text { point }\end{array}$ & $\begin{array}{l}\text { Conclusi } \\
\text { on }\end{array}$ \\
\hline Q1 & 0,461 & 0,013 & 0,374 & Valid & & & \\
Q2 & 0,623 & 0,000 & 0,374 & Valid & & \\
Q3 & 0,457 & 0,015 & 0,374 & Valid & & \\
Q4 & 0,614 & 0,001 & 0,374 & Valid & & \\
Q5 & 0,471 & 0,011 & 0,374 & Valid & & \\
Q6 & 0,698 & 0,000 & 0,374 & Valid & & \\
Q7 & 0,576 & 0,001 & 0,374 & Valid & & \\
Q8 & 0,603 & 0,001 & 0,374 & Valid & & \\
Q9 & 0,512 & 0,005 & 0,374 & Valid & & & \\
Q10 & 0,639 & 0,000 & 0,374 & Valid & & & \\
Q11 & 0,665 & 0,000 & 0,374 & Valid & & & \\
Q12 & 0,418 & 0,027 & 0,374 & Valid & & & \\
Q13 & 0,679 & 0,000 & 0,374 & Valid & & & \\
Q14 & 0,741 & 0,000 & 0,374 & Valid & & & \\
Q15 & 0,744 & 0,000 & 0,374 & Valid & & \\
Q16 & 0,768 & 0,000 & 0,374 & Valid & & \\
\hline
\end{tabular}

The validity test was carried out by using the Pearson correlation method. If the value of the correlation r-observation (rob) obtained is greater than that of the r-critical value (rcv), it is concluded that the question is valid. In the number of samples $(\mathrm{N}) 28$, the value of the r-critical 
value is 0.374 . Based on the table above, the lowest calculated r-observation is 0.418 in Q12 and the highest calculated r-observation is 0.768 in Q16. Since all questions have a calculated robservation greater than the r-critical value, it is concluded that all questions are valid.

The reliability test was carried out in this study using the Cronbach alpha method. If the alpha value of Cronbach is greater than its critical point, which is 0.7 , it is concluded that the variable is reliable. Based on the table above, the Cronbach's alpha value obtained was 0.882. As the value is greater than 0.7 , it is concluded that the data is reliable.

In analyzing the data, the researcher used descriptive statistical analysis by looking for the average value of the data. The average value obtained is entered into the following categories:

Table 2. Category

\begin{tabular}{ll}
\hline Interval & Category \\
\hline $1,00-2,33$ & Low \\
$2,34-3,66$ & Medium \\
$3,67-5,00$ & High \\
\hline
\end{tabular}

The following is the calculation result for each question:

Table 3. Participants' Responses

\begin{tabular}{|c|c|c|c|c|c|c|c|c|c|}
\hline \multirow{2}{*}{ Items } & & SA & $\mathbf{A}$ & $\mathbf{N}$ & D & SD & \multirow{2}{*}{ Score } & \multirow{2}{*}{ Mean } & \multirow{2}{*}{ Category } \\
\hline & & 5 & 4 & 3 & 2 & 1 & & & \\
\hline \multirow{2}{*}{ Q1 } & $f$ & 1 & 17 & 9 & 1 & 0 & \multirow{2}{*}{102} & \multirow{2}{*}{3.64} & \multirow{2}{*}{ Medium } \\
\hline & $\%$ & $3.6 \%$ & $60.7 \%$ & $32.1 \%$ & $3.6 \%$ & $0.0 \%$ & & & \\
\hline \multirow{2}{*}{ Q2 } & $\mathrm{f}$ & 1 & 2 & 16 & 8 & 1 & \multirow{2}{*}{78} & \multirow{2}{*}{2.79} & \multirow{2}{*}{ Medium } \\
\hline & $\%$ & $3.6 \%$ & $7.1 \%$ & $57.1 \%$ & $28.6 \%$ & $3.6 \%$ & & & \\
\hline \multirow{2}{*}{ Q3 } & $\mathrm{f}$ & 2 & 9 & 14 & 3 & 0 & \multirow{2}{*}{94} & \multirow{2}{*}{3.36} & \multirow{2}{*}{ Medium } \\
\hline & $\%$ & $7.1 \%$ & $32.1 \%$ & $50.0 \%$ & $10.7 \%$ & $0.0 \%$ & & & \\
\hline \multirow{2}{*}{ Q4 } & $\mathrm{f}$ & 0 & 8 & 9 & 11 & 0 & \multirow{2}{*}{81} & \multirow{2}{*}{2.89} & \multirow{2}{*}{ Medium } \\
\hline & $\%$ & $0.0 \%$ & $28.6 \%$ & $32.1 \%$ & $39.3 \%$ & $0.0 \%$ & & & \\
\hline \multirow{2}{*}{ Q5 } & $\mathrm{f}$ & 5 & 12 & 10 & 1 & 0 & \multirow{2}{*}{105} & \multirow{2}{*}{3.75} & \multirow{2}{*}{ High } \\
\hline & $\%$ & $17.9 \%$ & $42.9 \%$ & $35.7 \%$ & $3.6 \%$ & $0.0 \%$ & & & \\
\hline \multirow{2}{*}{ Q6 } & $\mathrm{f}$ & 2 & 17 & 9 & 0 & 0 & \multirow{2}{*}{105} & \multirow{2}{*}{3.75} & \multirow{2}{*}{ High } \\
\hline & $\%$ & $7.1 \%$ & $60.7 \%$ & $32.1 \%$ & $0.0 \%$ & $0.0 \%$ & & & \\
\hline \multirow{2}{*}{ Q7 } & $\mathrm{f}$ & 4 & 16 & 6 & 2 & 0 & \multirow{2}{*}{106} & 270 & Wist \\
\hline & $\%$ & $14.3 \%$ & $57.1 \%$ & $21.4 \%$ & $7.1 \%$ & $0.0 \%$ & & 3.19 & Hign \\
\hline $\mathrm{O} 8$ & $\mathrm{f}$ & 1 & 10 & 16 & 1 & 0 & & & \\
\hline Q8 & $\%$ & $3.6 \%$ & $35.7 \%$ & $57.1 \%$ & $3.6 \%$ & $0.0 \%$ & 95 & 3.39 & Medium \\
\hline Q & $\mathrm{f}$ & 7 & 15 & 6 & 0 & 0 & 113 & 404 & \\
\hline Q9 & $\%$ & $25.0 \%$ & $53.6 \%$ & $21.4 \%$ & $0.0 \%$ & $0.0 \%$ & 113 & 4.04 & High \\
\hline O10 & $\mathrm{f}$ & 3 & 16 & 7 & 2 & 0 & 104 & 371 & Hish \\
\hline Q 10 & $\%$ & $10.7 \%$ & $57.1 \%$ & $25.0 \%$ & $7.1 \%$ & $0.0 \%$ & 104 & 3.11 & Hign \\
\hline O11 & $\mathrm{f}$ & 2 & 12 & 12 & 2 & 0 & 08 & 350 & \\
\hline Q11 & $\%$ & $7.1 \%$ & $42.9 \%$ & $42.9 \%$ & $7.1 \%$ & $0.0 \%$ & 98 & 3.50 & Medium \\
\hline (1) & $\mathrm{f}$ & 1 & 18 & 8 & 1 & 0 & 103 & 368 & Hish \\
\hline Q12 & $\%$ & $3.6 \%$ & $64.3 \%$ & $28.6 \%$ & $3.6 \%$ & $0.0 \%$ & 103 & 3.08 & Hign \\
\hline O13 & $\mathrm{f}$ & 1 & 14 & 12 & 1 & 0 & 99 & 3.54 & Medium \\
\hline Q15 & $\%$ & $3.6 \%$ & $50.0 \%$ & $42.9 \%$ & $3.6 \%$ & $0.0 \%$ & 99 & 5.04 & Iviedintin \\
\hline
\end{tabular}




\begin{tabular}{llllllllll} 
& $\mathrm{f}$ & 3 & 15 & 10 & 0 & 0 & 105 & 3.75 & High \\
Q14 & $\%$ & $10.7 \%$ & $53.6 \%$ & $35.7 \%$ & $0.0 \%$ & $0.0 \%$ & & & \\
& $\mathrm{f} 15$ & 2 & 13 & 13 & 0 & 0 & 101 & 3.61 & Medium \\
& $\%$ & $7.1 \%$ & $46.4 \%$ & $46.4 \%$ & $0.0 \%$ & $0.0 \%$ & & & \\
Q16 & $\mathrm{f}$ & 0 & 4 & 11 & 10 & 3 & 72 & 2.57 & Medium \\
\multicolumn{2}{l}{ Overall Average } & $0.0 \%$ & $14.3 \%$ & $39.3 \%$ & $35.7 \%$ & $10.7 \%$ & & $\mathbf{3 . 4 8}$ & Medium \\
\hline
\end{tabular}

\section{The First Semester Students' Perceptions of Blended Learning via Schoology in Reading Class}

Q1. Blended learning via Schoology makes lectures more efficient in the Reading class. There were 17 students (61\%) who agreed that Schoology-based Blended learning makes lectures more efficient in the learning process in the Reading class.

Q2. Blended learning via Schoology is boring. Most students said neutral (57\%) if Schoology-based blended learning was boring. However, there were 8 students (29\%) who disagreed with the question.

Q3. Blended learning via Schoology is interesting to use.

It can be illustrated that 14 students $(50 \%)$ said neutral towards questions related to Schoology-based Blended learning which was interesting to use, while 9 students (32\%) agreed and 2 students (7\%) strongly agreed to the question.

Q4. Blended learning via Schoology is very difficult to be exploited in the Reading class. There were 11 students (39\%) who disagreed with the question that blended learning via Schoology was very difficult to be exploited in the Reading class, while 9 students (32\%) said neutral towards this statement.

Q5. The lecturer provides textbooks and PDFs during face-to-face learning. There were 12 students $(43 \%)$ who agreed that the lecturer provided textbooks and PDFs during face-to-face learning to support the teaching and learning process in the Reading class.

Q6. The lecturer provides extensive information to support online learning. There were 17 students (61\%) who agreed and 2 students (7\%) strongly agreed if the lecturer provided extensive information to support online learning.

Q7. Blended learning can improve student communication with lecturers, and students with other students not only during face-to-face learning but during online learning also with the support of other online media such as Whatsapp groups and email. Almost all students, 16 students (57\%) agreed and 4 students (14\%) strongly agreed with the question that Blended learning can improve student communication with lecturers, and students with other students not only during face-to-face learning but also during online learning, which is supported by other online media such as Whatsapp groups and email.

Q8. I feel motivated to explore lecture material in Schoology-based blended learning. There were 16 students (57\%) who said neutral towards the statement "I feel motivated to 
explore course material in Schoology-based blended learning". However, 10 out of 28 students (36\%) and 1 student (4\%) agreed to this statement.

Q9. I can study anytime and anywhere to increase my knowledge by using Schoology. Almost all students, 15 students (54\%) agreed and 7 students $(25 \%)$ strongly agreed with the statement "I can study anytime and anywhere to increase my knowledge".

Q10. I find it easier to submit assignments anytime and anywhere by using Schoology. Almost all students, 16 students (57\%) agreed and 3 students (11\%) strongly agreed with the statement "I find it easier to collect assignments anytime and anywhere".

Q11. Schoology-based blended learning makes students more motivated in the learning process. There were 12 students (43\%) who agreed and 2 students $(7 \%)$ strongly agreed with the question that Schoology-based blended learning was able to make them more motivated in the learning process.

Q12. Schoology-based blended learning can help students to manage their time to study. There were 18 students (64\%) who agreed and 1 student (4\%) strongly agreed with the question that Schoology-based blended learning was able to help them to manage their time to study.

Q13. Schoology-based blended learning can make students more active in the Reading class. There were 14 students (50\%) who agreed and 1 student (4\%) strongly agreed with the question that Schoology-based blended learning can make them more active in the Reading class.

Q14. Schoology-based blended learning can make the students more challenged and responsible in the Reading class. There were 15 students (54\%) who agreed and 3 students (11\%) strongly agreed with the question that Schoology-based blended learning was able to make them more challenged and responsible in the Reading class.

Q15. Schoology-based blended learning can make students more focused in the Reading class. There were 13 students $(46 \%)$ who agreed and 2 students $(7 \%)$ strongly agreed with the question that Schoology-based blended learning was able to make them focused more in the Reading class.

Q16. Schoology-based blended learning is not effective, it just wastes time for the students in the Reading class. There were 10 students (36\%) who disagreed and 3 students (11\%) strongly disagreed with the question that Schoology-based blended learning is not effective, it just wasted their time in the reading class.

\section{The First Semester Students' Attitude on Blended Learning via Schoology in Reading Class}

The features designed in the application here include interaction, technology with its quality, face-to-face support, and learning management system tools and resources. Initially, the researcher described the data from the observation sheet in the learning process. At first, students were introduced to blended learning via Schoology. There were $80 \%$ of students who were very enthusiastic about the features. Students learn how to use Schoology as an instructor and as a student menu. The hierarchical steps to register are:

1. Go to www.schoology.com

2. Click Register 
3. Select the instructor, student, or parent menu

4. Fill in the blank fields for the first name, last name, email, password, and confirm password. In the menu, students must access the code to enter the class group.

5. After registering, a verification sign will appear and will be sent via an email address, the verification process is carried out, then registration is complete.

6. Finally, you will enter the Schoology application as shown below

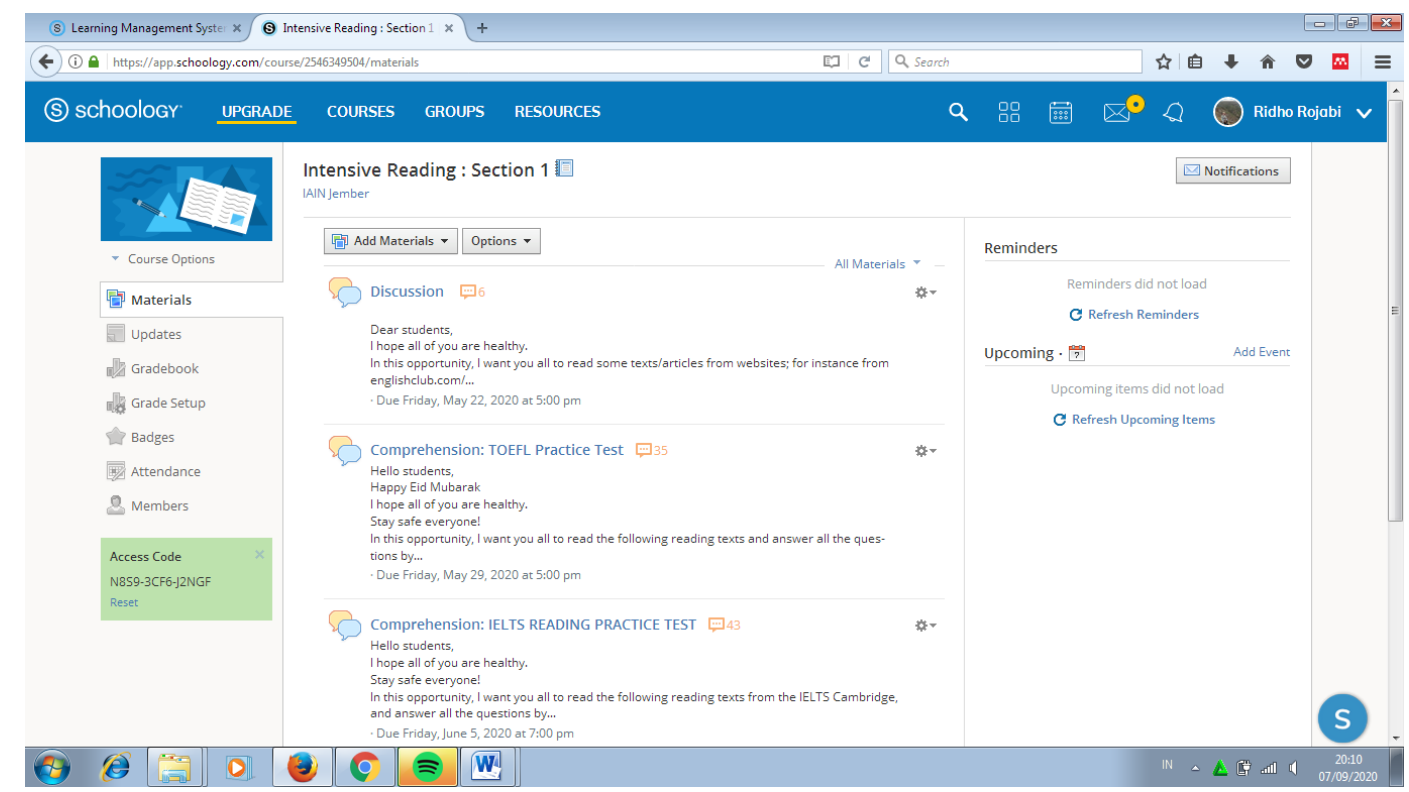

Figure 1. Schoology Application in Reading Class

Students do not experience difficulties in the registration process or logging in. However, technically there was a disruption to registration and logging in due to low internet connection services so that some students were forced to leave the classroom to find another router access to get an internet signal.

Learning material is included in blended learning via Schoology. After being told how to upload and download, no one found it difficult to do so. In fact, they were happy as it was very easy to access learning materials. Ease of accessing learning material makes study time more effective which has an impact on student learning motivation. In learning activities, motivation is the important aspect for students that leads to learning activities and ensures the continuity of learning activities.

Most students do not have difficulty downloading the assignments given during face-toface learning. They were serious but still relaxed in their duties. However, some students did assignments while browsing the other webs such as Facebook. Lecturers should pay attention to students who are more focused on doing other things. This makes students more self-aware not to open another web. Lecturers provide homework through Schoology. Submitting homework can be done anywhere and anytime. Assessment is done on distance learning, in this case, it is done virtually. Based on the results of observations, students were very enthusiastic in answering the questions given by the lecturer. The Lecturer provided stimulation to students such as gifts if 
students did well on exams. Giving rewards was one way to motivate students to access Schoology frequently, to actively discuss, and to gain knowledge deeper.

At the second meeting, students got a quiz during face-to-face learning. The lecturer arranged a quiz that had to be done three times in Schoology. So if students are in doubt about the answers to the quiz, they will repeat them to get better results. This is done so that students are motivated to increase the value obtained in the first quiz assignment. It will also solve internet connection problems. Two students were disadvantaged due to internet connection problems. Their desire to increase grades is reduced due to connection problems. The quiz closed by itself as if they had finished working on it. The solution given at that time was to repeat the quiz. If this doesn't work, they write the answers down on paper to increase their score. Most of them were challenged by the quiz because it only took one minute for one question. If they can't do it, then move on to the next question. The quiz scores can be seen directly from the students, making them more enthusiastic about doing the quizzes. Of the three quizzes, they got the best score.

\section{Benefits and Challenges of Blended Learning via Schoology in Reading Class}

To find out the benefits of blended learning via Schoology, there is an open questionnaire about the benefits of Schoology-based blended learning given to students. The researcher had summarized some of the answers from 28 respondents. In summarizing the respondents' answers, there are three parts of the benefits of blended learning via Schoology. These benefits are; get lots of reading resources, easy to use in online learning, and can relearn the difficult material, submit assignments anytime and anywhere.

According to student A, he said that "I get a lot of reading resources on the Schoology application, besides that, I can be more responsible in submitting assignments because they can be done anytime and anywhere". So, Schoology provides benefits to provide time flexibility for students in submitting assignments. Meanwhile, student B, stated: "I am more focused on learning because Schoology is easy to use and can repeat difficult material". Meanwhile, student $\mathrm{C}$ said that "I learned a lot of reading sources uploaded by the lecturer in both pdf and link forms".

There is an open questionnaire on the challenges of blended learning through Schoology to find out the challenges of learners while taking tests in Schoology. Some of the responses from 28 respondents were summarized by a researcher. In summarizing the participants' answers, there are three parts to students' challenges when taking online tests on Schoology according to participants. These challenges are dealing with time, internet connection, and application problems.

According to student $\mathrm{A}$, he said that "The challenge is actually related to the time given during the online assessment, sometimes the time given is not proportional to the level of difficulty in doing the questions. Sometimes due to limited connections on campus, it is also inefficient when I want to work on campus with friends." The challenge is dealing with limited time for answering questions and the poor connection during answering questions. Another view 
is from student B, who said that "Sometimes if you want to submit assignments, there are errors on Schoology application." "The task was sent but no assignment." This response is about the problem with the Schoology application. Another challenge came from student $\mathrm{C}$, who said that "The challenge is we have to answer questions and submit it quickly because there is a notification if we submit it late and we cannot get a good score." The challenge of student $\mathrm{C}$ is about the limited time in answering quizzes on Schoology. Those are three answers from 28 respondents about their challenges in submitting tasks, joining the quiz, or taking tests on Schoology.

\section{Discussion}

\section{A. EFL Students' Perception of Blended Learning via Schoology}

The results of this study indicated that students have a positive perception of blended learning via Schoology. There are several reasons why students have positive responses to the use of online examinations. Firstly, they prefer to use online examination because it is very convenient to use Schoology and most students are familiar with Schoology's features. They also know technology before the use of Schoology. As suggested by Davies (2011), students can work more efficiently if they are aware of the available technology for understanding and evaluating the technology integration efforts in the teaching and learning process. Thus, comprehending technology is required for the teachers as well the learners in exploiting Schoology properly.

The second reason why students are interested in using online assessments is that online assessments are better than paper assessments. The characteristics of Schoology are visualized in an attractive and interactive visual appearance. It is supported by previous research that Schoology content has creative features where users can upload images, animation, audio-video (Rojabi, 2019; Yoshida, 2018). On the contrary, the assessment of the paper is monotonous. In written assessment or paper assessment, there are no additional media like the online assessment. Therefore, students feel interested in doing online assessments on Schoology. This finding is in line with the previous which revealed that students prefer to take online tests rather than written tests (Marriott, 2009). Therefore, the fulfillment of interesting features on Schoology can trigger students' desire to do online assignments.

The third reason why students are interested in Schoology's application is due to the flexibility and ease to use. By using Schoology, students can take the exams anywhere and at any time as the deadline is set on the website. Besides, using Schoology can also be managed everywhere without bringing the test in class with the teacher. This finding was confirmed by the previous research that Schoology as an online learning platform is flexible, fun-featured, easy-touse for creating, sharing, and submitting academic assignments (Ferdianto \& Dwiniasih, 2019). In this case, one of Schoology's good features is practical and flexible, which can save users time.

However, although the students argued about positive perceptions in the use of online learning in Schoology, some students also stated that the use of online learning in Schoology also presented negative perceptions. They argue that online assignments may be problematic and 
complicated. It is supported by the previous research that students can face problems with internet access, large data, and difficulty in applying group assignments (Murad et al., 2020). Apart from the problem regarding the use of blended learning with Schoology, some students also felt that the learning system was complicated. They are sometimes confused when taking quizzes or exams because of a lack of understanding regarding the use of online systems.

\section{B. EFL Students' Attitude of Blended Learning via Schoology in Reading Class}

From the results of observations made by the researcher, it turns out that in a class with 28 students, their attitudes when they are in class, they take the back seat, the most corner, or take a place in the middle of the room. The reason why they chose the two-seat options was that it was the most strategic place for them to open their cellphones and access Schoology as well as access the internet to get information related to the required tasks. Regarding the choice of place to study, of course, they have gone through the learning process as said by Koentjaraningrat (2019), he confirmed that without going through the learning process, they will not know where is the right place and at what time they have to open the learning application. This attitude is of course exemplified by a friend who initially did this and was then followed by other students.

When there are questions from lecturers, students often immediately open their cellphones and search for answers via Google.com or try to translate the reading text assignments given by the lecturer on the Schoology application. Even though the questions given by the lecturer are to invite students to analyze and think critically as the questions cannot be found in the reading text nor by browsing the internet.

From the aspect of comparison with conventional learning, students still tend to choose conventional learning as they can directly get information from the lecturer. So that when they get new learning innovations, educators and students tend to be slow to understand how to exploit the innovations. Some students initially also expressed difficulties when accessing Schoology due to limited data or internet quotas as well as limited knowledge in technology. This is in line with the findings of the previous research that educators had not maximally implemented blended learning. It can be seen that educators only take advantage of the assignment and material sharing features. And when educators provide discussion features to increase student interaction in online learning, in application students only provide copy and paste answers. In brief, there is no interaction in asynchronous online learning.

\section{The Benefits and Challenges of Blended Learning via Schoology}

The learning materials which are uploaded on Schoology are supported by several interesting features, and it attracts the students. After being told how to upload and download, no one found it difficult to do so. They are interested as it is very easy to access learning materials on Schoology. The ease of accessing learning material makes the study more effective, and it impacts student learning motivation. According to (Levpuscek \& Zupancic, 2008), one of the factors that determine student success in the learning process is motivation. In learning activities, 
motivation is the important aspect that leads students to engage in learning activities and ensures the continuity of learning activities.

In an aspect of time efficiency, it provides convenience to students and lecturers regarding time limitations. Learning that cannot be done face-to-face can be replaced by online learning via Schoology so that fewer meetings can be overcome by reading the texts and submitting tasks on the Schoology platform. This is following the previous research which shows that the results of Schoology-based blended learning are effective, and exploiting Schoology in online learning can be done anytime and anywhere (Indrayasa et al., 2015).

Although the results obtained show that students have positive perceptions of blended learning via Schoology, but there are challenges from students in blended learning via Schoology. The findings from this study indicate that there are several challenges faced by students when using Schoology; time, internet connection, system problems, and controllers.

The first challenge is dealing with time, students say they have to work quickly and precisely because of limited time, they cannot relax in taking online tests as they are afraid of limited time, and some tasks that need to be done. In this case, students feel that doing an online test is complicated due to limited time. This may happen because they are accustomed to using written tests where each question is not limited by the time, and when they first use the online test, they feel complicated due to limited time. Although the written test still has a limited time, the online test on Schoology provides a time limit for each question and, if the time is up, it is considered not to fill in the answer. It is also confirmed that time limit challenges can be limited by the availability of test time for students (Sanli, 2003). Therefore, students must be able to manage and take online tests quickly and responsively as they are limited by time,

The second challenge faced by students is dealing with the internet signal, where most of them feel annoyed when they have to answer the questions but there is poor so that students cannot answer some questions properly. This is in line with the previous research which confirmed the constraints of online learning, especially dealing with an unstable connection problem, internet connection is very important in carrying out online learning. If the connection is poor, as a consequence, it will not be successful in implementing online learning (Bhalalusesa et al., 2013; Mtebe \& Raphael, 2013). Therefore, when it was announced that there would be an online Schoology exam, students had to prepare their computers, mobile phones, student readiness, and internet signals during the online test. In some cases, students should go to places where there is a good and stable signal, thus, students can comfortably take the online test without being hindered by poor internet signal.

The third is dealing with the application problem. This is not related to the application problem, but it deals with the students' confusion during the online tests on Schoology. It happens as students have never previously taken online tests so that they are confused about how to deal with it. However, students can access, download, as well as upload the task easily on Schoology. One of the challenges in online assessment is the lack of experience and knowledge of students in exploiting computers and the online assessment process. As explained above, they found it easy to use the online test application on Schoology, but they were frustrated during the 
online test and dealt with the issues as they were complicated and the online test process was confusing (Alruwais et al., 2016).

Therefore, students must understand the materials that have been taught by the lecturer so that they are not confused or difficult when doing online tests on Schoology. Moreover, if students have difficulty in the process of answering questions, the lecturer has the responsibility to guide them in the online test process.

The last challenge is about controllers, the absence of controllers during online tests becomes a challenge for students. Unfortunately, students feel enthusiastic when answering questions or post ideas in the comment field and no one controls them. Most students agree that when the online test takes place, they can take the test anywhere without the presence of the teacher. From the results of the data, it was found that students felt happy because they were able to do online tests without a controller. This contrasts with previous research conducted by (Sanli, 2003), he states that another problem in online assessment is the lack of teacher control over the assessment conditions because students took quizzes/exams remotely, and there is no way of knowing whether the quiz/test was taken by students enrolled in the course and whether they did the quiz/test without the help of other students or assistance from material sources or books. 72 Students enjoy the online test because no one controls them, in this case, they can either access internet sites or in books to find out the answers. However, due to time constraints, it is very difficult for them to find out answers on the internet or in books during the online test. Therefore, whether there is a controller or not during the online exam, students must continue to do the exam properly and correctly without having to cheat by looking for other answers. The best answer is the result of one's thoughts.

\section{Conclusion}

Based on the results of student perceptions, student attitudes, and the benefits and challenges of students in blended learning via Schoology, it was found that there were positive perceptions about Schoology-based blended learning. The students are interested in the features provided by the Schoology application, and the easiness to use of this application during online learning. Another reason is by submitting assignments online or re-accessing the materials on Schoology, the learners can save time, and they can do it anytime and anywhere rather than paper assignments.

However, there are still some challenges faced by students in Schoology-based blended learning. Based on the research results, the challenges that students faced are dealing with time, internet signals, and technological capabilities. They feel challenged in taking the online test because they have to be fast in answering time-limited questions. Another challenge is when there is a slow, bad signal during an online exam and this irritates them because they could have missed a question or two. Besides, the online assessment process can sometimes confuse them during exams. 
It is recommended for the English teachers and future researchers to exploit blended learning via Schoology to enhance the EFL students' reading comprehension, students' motivation as well as learners' autonomy both online and in the classroom setting.

\section{References}

Alruwais, N., Wills, G., \& Wald, M. (2016). Identifying factors that affect the acceptance and use of E-assessment by academics in Saudi Universities. IJAEDU - International E-Journal of Advances in Education, 2(4), 132-140. https://doi.org/http://dx.doi.org/10.18768/ijaedu.20012

Bernard, Z. (2017). Here's how technology is shaping the future of education. https://www.businessinsider.com/how-technology-is-shaping-the-future-of-education-201712 ? $\mathrm{r}=\mathrm{US} \& \mathrm{IR}=\mathrm{T}$

Bhalalusesa, R., Lukwaro, E. E., \& Clemence, M. (2013). No Title. Huria Journal of OUT, 14, 89-110.

Biswas, S. (2018). Schoology-supported classroom management: a curriculum review. The Northwest of Journal Teacher https://doi.org/https://doi.org/10.15760/nwjte.2013.11.2.12

Butler-Pascoe, M. E., \& Wiburg, K. M. (2003). Technology and teaching english language learners. Pearson College Division. https://scholar.google.com/scholar?oi=bibs\&cluster=13372377541470257068\&btnI=1\&hl= en

Christianti, P. (2020). Tenth grade students' perception of developed online reading materials through schoology. Widya Mandala Catholic University Surabaya.

Davies, R. S. (2011). Students can work more efficiently if they are aware with the available technology for understanding and evaluating the technology integration efforts in the teaching and learning process. TechTrends, 55(5), 45-52. https://doi.org/doi:10.1007/s11528-011-0527-3

Dreyer, C., \& Nel, C. (2003). Teaching reading strategies and reading comprehension within a technology-enhanced learning environment. System, 31(3), 349-365. https://doi.org/https://doi.org/10.1016/S0346-251X(03)00047-2

Ferdianto, F., \& Dwiniasih. (2019). Learning Management System (LMS) schoology: Why it's important and what it looks like. International Symposium on Sciences, Engineering, and Technology. https://doi.org/doi:10.1088/1742-6596/1360/1/012034

Garrison, D. R., \& Vaughan, N. D. (2008). Blended learning in higher education. John Wiley \& Sons, Inc.

Hong, K. ., Ridzuan, A. A., \& Kuek, M. . (n.d.). Students' attitudes toward the use of the Internet for learning: A study at a university in Malaysia. Educational Technology and Society, 6(2), $45-49$.

$\mathrm{Hu}, \mathrm{G}$. (2010). Recent important developments in secondary english-language teaching in the
people's
republic
of
china.
$15(1)$,
$30-49$. 
https://doi.org/https://doi.org/10.1080/07908310208666631

Indrayasa, K. B., Gede Agung, A. A., \& Mahadewi, L. P. P. (2015). Pengembangan e-Learning dengan schoology pada mata pelajaran bahasa indonesia untuk siswa kelas X semester I tahun pelajaran 2014/2015 di SMA N 4 Singaraja. Jurnal Edutech UNDIKSHA, 3(1). https://doi.org/http://dx.doi.org/10.23887/jeu.v3i1.4835

Koentjaraningrat. (2019). Pengantar ilmu antropologi. Rineka Cipta.

Kukulska-Hulme, A. (2009). Will mobile learning change language learning? ReCALL, 21(2), 157-165. https://doi.org/https://doi.org/10.1017/S0958344009000202

Kumar Basak, S., Wotto, M., \& Be'langer, P. (2018). E-learning, M-learning and D-learning: Conceptual definition and comparative analysis. E-Learning and Digital Media, 15(4), 191216. https://doi.org/http://dx.doi.org/10.1177/2042753018785180

Levpuscek, M. P., \& Zupancic, M. (2008). Math achievement in early. Journal of Early Adolescence, $X X(\mathrm{X}), 1-30$. https://doi.org/http://doi.org/10.1177/0272431608324189

Littlejohn, A., \& Pegler, C. (2007). Preparing for blended e-learning. Routledge.

Low, P. (2017). E-learning implementation in foundation english class: learners' perspectives and learning achievement. International Journal of Computer Theory and Engineering, 9(4), 285-289. https://doi.org/DOI: 10.7763/IJCTE.2017.V9.1153

Marriott, P. (2009). Students' evaluation of the use of online summative assessment on an undergraduate financial accounting module. British Journal of Educational Technology, 40(2), 237-254. https://doi.org/https://doi.org/10.1111/j.1467-8535.2008.00924.x

Mehdipour, Y., \& Zerehkafi, H. (2013). Mobile learning for education: benefits and challenges. International Journal of Computational Engineering Research, 3(6).

Moore, M. G. (2013). Handbook of distance education (third edition). Routledge.

Mtebe, J. S., \& Raphael, C. (2013). Students' experiences and challenges of blended learning at the University of Dar es Salaam, Tanzania. International Journal of Education and Development Using Information and Communication Technology (IJEDICT, 9(3), 124-136. https://www.learntechlib.org/p/130276/

Murad, M. A., Asriadi, Hadi, S., Mubaraq, R., Sastrawan, E., \& Zahra, F. (2020). No title. Proceedings of the International Conference on Community Development (ICCD 2020), 455-458. https://doi.org/https://dx.doi.org/10.2991/assehr.k.201017.100

Oroujlou, N., \& Vahedi, M. (2011). Motivation, attitude, and language learning. Procedia Social and Behavioral Sciences, 29, 994-1000. https://doi.org/https://doi.org/10.1016/j.sbspro.2011.11.333

Poon, J. (2013). Blended learning: an institutional approach for enhancing students' learning experiences. MERLOT Journal of Online Learning and Teaching, 9(2), 271-288. http://dro.deakin.edu.au/view/DU:30057995

Rojabi, A. R. (2019). Blended learning via schoology as a learning management system in reading class: benefits and challenges. Jurnal Linguistik Terapan, 9(2), 36-42.

Sanli, R. (2003). Students' perception about online assessment: a case study. in the middle east technical university. http://etd.lib.metu.edu.tr/upload/2/1063650/index.pdf 
Susuwele-Banda, W. J. (2005). Classroom Assessment in Malawi: Teachers' Perceptions and Practices in Mathematics. Virginia Polytechnic Institute and State University.

Untari, M. B., Alaydrus, Y., \& Ni'mah, D. (2020). Learners' Perception on Their Online Reading Comprehension Learning at the English Education Department. Jurnal Penelitian, Pendidikan, Dan Pembelajaran, 15(28), 1-15. http://riset.unisma.ac.id/index.php/jp3/article/view/7584

Wanner, T., \& Palmer, E. (2015). Personalising learning: exploring student and teacher perceptions about flexible learning and assessment in a flipped university course. $\begin{array}{lllll}\text { Computers } \quad \& \quad \text { Education, } & 88,\end{array}$ https://doi.org/https://doi.org/10.1016/j.compedu.2015.07.008

Yoshida, M. T. (2018). Choosing Technology Tools to Meet Pronunciation Teaching and Learning Goals. The Catesol Journal, 30(1), 195-212. 